\title{
Market Ethic and Morality Transformation in Emerging Economies
}

Submitted 12/11/21, 1st revision 15/12/21, 2nd revision 17/01/22, accepted 10/02/22

\section{Fuan $\mathrm{Li}^{1}$}

\begin{abstract}
:
Purpose: The integration of transitional economies into the global economic system has led to unprecedented economic growth and prosperity in developing countries. In the meantime, moral degradation, inequities of wealth, corruption, and environmental deterioration are endemic of those countries. The present study aims to examine the role of market ethic in economic reform and morality transformation in transitional economies.

Design/Methdology/Approach: The economic reform undertaken in the largest transitional economy in the world is analyzed to reveal the critical role of market ethic in economic transition, and the importance of embracing ethics of justice in morality transformation.

Findings: The results show that market ethic is critical to the success of economic reform and that morality of justice is essential for regulating market force and providing the ethical foundation of the market. The findings of this study should enhance our understanding of the role of market ethic in economic reform and the importance of justice in transforming morality.

Practical Implications: This study should provide important guidance and invaluable insights for business managers as well as policy makers in emerging economies.

Originality value: The findings demonstrate that adopting a market economic system inevitably leads to changes in beliefs, values and ethical norms. Embracing ethics of justice is key to successful morality transformation in emerging economies.
\end{abstract}

Keywords: Economic reform, transitional economies, market ethic, morality of justice, moral transformation.

JEL classification: M140, L21.

Paper Type: Research article.

\footnotetext{
${ }^{1}$ Department of Management, Marketing, \& Professional Sales, William Paterson University, NJUSA, e-mail: lif@wpunj.edu;
} 


\section{Introduction}

Economic reform has facilitated integration of transitional economies into the global economic system, and consequently led to unprecedented economic growth and prosperity. However, inequities of wealth, unfair labor policy, environmental deterioration and moral degradation are endemic of emerging economies such as China (Javalgi and Rusell, 2018; Li et al., 2015; Salvador, 2019). Unethical business practices in the area of product safety, information disclosure, employee relation and so on have been widely reported in the media. Faced with the challenge presented by the emerging markets, business researchers have made tremendous effort to explore causes that are accountable for the chaotic situation and the potential ways to fight against ethical problems in those economies.

Previous research has shown that the underdeveloped institutional environment, inadequate government and/or professional regulation, weak legal enforcement and lack of public transparency all contributed the ethical chaos (Tan 2009; Hashimi et al., 2015). Nevertheless, recent experience of China seems to indicate a need for a further understanding of the nature of the observed ethical chaos. Chinese government has made great progress in improving the institutional environment, tightening state control and strengthening regulations.

However, unethical and/or illegal business practices still widespread despite the government's crack-down effort. What we observed in China made it imperative to examine the role of market ethic in emerging economies and the need for transforming the extant normative ethics in those countries. Previous research shows that market ethic resulting from economic reform is accountable for the dramatic changes in emerging markets, including ethical problems we have observed (Berger, 2015; Redfern and Crawford, 2004).

For instance, the transition of China from a centrally planned economy to a market economy has brought in values, norms, and institutions that are essential to effective function of a market economy but incompatible, or even conflicting with the existing value system. Such changes inevitably lead to disruption to extant moral beliefs, principles and social norms. One of the consequences of such changes concerns an emerging culture of "profit at any cost," which results in "the rapid rise of the unethical corporations - groups of companies operating unethically on a massive scale" (Ip, 2009, p. 214). Findings from previous research have shown how important it is to understand the changes market ethic brings to the transitional economies, especially its implications on morality in those countries.

Given the role played by market ethic in disrupting existing normative ethics and nurturing a culture of profit, it is imperative to examine how market ethic impacts morality in emerging economies and how normative ethics associated with market ethic may contribute to morality transformation. The present study attempts to contribute to the literature by thoroughly examining the true nature of market ethic 
and its role in shaping and disrupting moral systems in emerging countries, and by looking into the need for emerging countries to embrace morality of justice in transforming morality. In that which follows, this paper will first review the role of market ethic in economic reform and its impact on normative ethics in those transforming economies. Then, it will shift to discussing the nature of morality of justice and its role in moral transformation. Finally, the implication of this study for marketers and policy makers in emerging economies will be discussed.

\section{Economic Reform in China and the Impact of Market Ethic}

Before the economic reform started in 1978, the economic system in China was a central planned economy, as seen also in Eastern Europe and the former Soviet Union. The key feature of planned economies is the use of central planning and bureaucratic control by the government. The central planning committee determined the level of production and distribution of products and services. With the exception of labor, factors of production were all owned by the state or collectives. The firms took order from the planning regime and had no incentive to improve financial performance for they were not independent or autonomous business units, thus not concerned about profitability.

Prior to the economic reform, the doctrines dominated in China were anti-capitalism, class struggle, and dictatorship of the proletariat, which exhorted suppressing personal egos and self-interest, and advocated selfless devotion to the motherland, collectivism, loyalty to community, patriotism and serving the people. The ideology was culminated in the so-called Cultural Revolution, which thoroughly revealed the destructive sides of the ideology that locked people in a spiral of poverty, ignorance, fear, mistrust, and backwardness.

China started its economic liberalization under the leadership of Deng Xiao Ping, the chief engineer of the economic reform. The reform began with a moderate change to the existing economy with market playing a supplementary role. As the government targeted so-called socialist commodity market, the role of central planning was gradually reduced and market regulation strengthened. The $14^{\text {th }}$ Party Congress held in 1992 formally announced the beginning of a socialist market economy. Since then, China has undergone rapid fundamental transformations (Hanafin, 2002).

The economic reform period following the Cultural Revolution entailed sharp criticism of prior ideology. In fact, Deng Xiao ping's proclamation that "to get rich is glorious" introduced a new market ethic, where economic development assumed top priority and profit became the primary, overriding goal. The focus of the country shifted from class struggle theories to economic development, from political passion to materialistic civilization, and from ideological dogmatism to pragmatism. As economic performance and productivity became the center of the focus, people were granted the permission to pursue their personal interest, and hence market, profit, and wealth, were perceived in a positive light, no longer seen as evil as in the past. 
Separation of public administration from party affairs, and enterprises from governments lead to restructuring of state-owned enterprises, and privatization. In the end, a market economy characterized by multiple ownership gradually replaced the central-panned economy $(\mathrm{Li}, 2018)$. "The centrally planned economy system with single public ownership and the unity of ownership and managements was changed into the de-centralized market economy system with diversified ownership and separation of ownership and management" (Lu, 1997, p. 1511).

The economic reform freed people from years of misery and ideological bondage. People were encouraged to do all they can to get rich. Peasants were granted the freedom to decide what to do with the land allocated to them, private businesses were given permission to operate their own way, and contractual responsibility were introduced to link payments to outputs and rewards to contributions. All those changes indicate that economic reform has inevitably led China to adopt market ethic, which freed China from dogmas in the past and brought liberation to Chinese society. The introduction of market ethic declared the beginning of new era in modern Chinese history.

What follows is more than forty years of economic growth. The success of the reform has made China the second economic superpower in the world. As a result, hundreds of millions of Chinese were lifted from poverty while millions were becoming members of the middle class. In the meantime, under the banner of building socialist market economy with Chinese characteristics, Chinese have experienced drastic transformation in all aspects of their life. It is probably fair to say that if it were not for Deng's leadership, China would not have been where it is today.

As economic reform in China illustrates, transforming economies are characterized by the adoption of a market economic system that unleashes humankind's productive energy and creativity. Dynamic economic changes embodied in division of labor, specialization, impersonal exchange, and privatization imply a fundamental change in the experiences of individuals as well as societies. Economic reforms ensue drastic changes in institutional framework, social organization, and belief and value systems.

As Chinese transition into a market economy, they inevitably adopted market ethic, a set of beliefs, values, and principles that are essential for a market economy to function (Balsiger, 2016; Maitland 1997; 2002). According to Adam Smith (Smith, $1776 / 2003$ ), a market economy is a system built on market exchange relationships and driven by the principle of rational self-interest. Market exchange concerns transfer of ownership of goods or services between two parties, the buyer who needs the product and the seller who wants to trade the ownership of goods or services for something of value. When describing the market mechanism, Smith writes, the rule in market exchange is "Give me that which I want, and you shall have this which 
you want." In such a relationship, each party to the exchange "intends only his own security," and "only his own gain." (Smith, 1776/2003, p. 572).

However, led by "an invisible hand," each man who pursues his own interest "frequently promotes that of the society more effectually than when he really intends to promote it." (ibid) Market exchanges assume that autonomous individuals who have different needs and preferences enter the exchange relationship of their own choice, for promotion of their self-interest. Hence, "The image of the instrumental value of self-love has become, in modern economics, the fundamental assumption" (Evensky, 2005, p. 110).

Furthermore, market relationships involve the transference of property ownership through fair and voluntary exchanges. A market-based economic system requires stability of property rights and freedom in transferring ownership of one's possession. In addition, market exchange relationships are of voluntary and contractual nature. If people agree that it is in the best interest of all concerned, then they enter the exchange voluntarily and bind themselves to accept the contractual agreement, which explicitly specifies, often formulated in the form of legal documents, about who should be doing what, the benefits and costs, and the timing of the interaction.

Therefore, besides individuals' right to pursue their personal interest, freedom of choice is also essential for effective function of a market economy. Each party to the exchange comes to the marketplace and selects the exchange partner of their own choice. They come together to obtain what they want according to an exchange ratio determined by the market. The outcome is the seller gives out the ownership of the product and the buyer obtains the ownership at the price level determined by the market. For this exchange to occur, both parties must acknowledge the right of the other's ownership of either the product or money, and respect the other's independent decision.

Freedom grants people the right to pursue their own interests without regard to the needs and desires of others and/or forcibly imposed social relational obligations. As widely recognized, the commoditization of labor, land, exchange, and time depends upon freedom to choose where to work, how to use land, what to produce and what to consume, and how to spend time.

In sum, rational self-interest, freedom of choice, right to property, and economic efficiency constitute the core of market ethic (Balsiger, 2016; Maitland, 1997; 2002). China's economic miracle is the modern copy of the Wealth of Nation. As the notion of free market is gradually embraced by most Chinese, they become increasingly to think themselves as self-interested home economicus, and accept market related conceptions such as rationality, freedom, democracy, profit, utility maximization, etc., to guide their behaviors. 
Despite its role in the subsequent success of the economic reform, market ethic encourages people to pursue wealth and profit, and thus fueling a culture of profitseeking. Understandably, perusing personal interest and wealth is no longer a sin, nor is sacrificing personal interest for public good an obligation. A culture of profit began to take root and people were pursuing profit for themselves and very often with socially undesirable consequences. The mentality of doing whatever you want to get rich is widespread, which drastically affects the social and cultural landscape. As reported in both local and international media, many companies with the profitat-any-cost mentality have created serious ethical violations, corruption, and injustice in businesses and society at large.

Lu (2009) holds that profit motivation, market demands, and competition pressures has driven some businesses to seek profit at any cost. When unstrained, rational selfinterest may bring all the evil as it did in the 18 and $19^{\text {th }}$ century. This especially true given the underdeveloped institutional environment. Peng et al. (1996) argue that economic reform in emerging countries put an end to central planning and bureaucratic control, and replaced those institutional forces with market-based institutions.

However, during the transition, institutional environments at best were inadequate. In the case of China we have witnessed lack of a property rights-based legal system, lack of strategic factor markets that facilitates the transfer of capital ownership, and unstable political structure. Inadequate institutional development (Peng et al., 1996) has certainly contributed to the widespread profit culture. Nonetheless, the chaotic situation in ideology, especially in both personal and social ethics are probably the prime mover of the shift to profit-seeking mentality. Ip (2009) argues that as China adopted transitions to a market economy, the dominant values and norms in Mao's era were either thrown into doubt or perceived to be irrelevant, and abandoned.

People's behaviors were largely shaped and motivated by naked self-interest and greed. The great disruption in values and norms nurtured an ethical environment of anomie. There were no shared acceptable norms of behavior, and the values to ground these norms were either confusing or nonexistent. In his opinion, the rapid rise of the unethical corporations is only one noticeable aftermath of this ethos.

Doubtlessly, market ethic has fueled the economic growth in China for it is critical to effective function of market economy. However, unbridled market forces may disruption the market resulting in undesired consequences. It is essential to change both the institutions and the belief systems for successful reform (North, 1995) because it is the mental models of the actors that will shape choices. While economic growth may occur in the short run with autocratic regimes, long-run economic growth entails the development of the rule of law, and the protection of civil and political freedoms. 
Thus, there is an urgent need for morality transformation or the making of a new type of morality, which will impose order and regulation on the market, and provide norms of behavior, conventions, and codes of conduct for a society founded on a market economic system.

\section{Embrace Ethics of Justice and Morality Transformation}

According to North (1990), changes in economic systems entail social, cultural, ideological changes. These changes need not to simply reflect the changes in economic base; in fact, they must provide the essential support needed by the economic system. A market economic system primarily driven by self-interest, of which the ties are defined by the allocation of goods and services. To function effectively and properly, a market economy requires a new moral system that is bent upon producing the best and most efficient allocation of resources while providing sufficient control and regulation on market forces.

Specifically, market ethic encourages the pursuits of personal interest, gain, happiness, thus essential for effective function of the market, but unbridled selfinterest would lead to disorder of the market and make it dysfunctional. A market economy needs an ethical foundation that provides the ethical values and principles that serve as the norms and standards for people's behaviors in the market as well as in society. Thus, a new type of morality that provides the essential regulative concept is necessary for proper function of the market and for the order of civil societies.

Smith is generally regarded as one of the pioneers for ethics of justice, the theory of morality essential to a market economy and modern society. To Adam Smith, liberty of action is not about freedom to do whatever the individual desires to do. In fact, Adam Smith recognizes the moral flaws of a commercial society and attempts to transcend the existing ethical model and establish a moral system better suited to the exigencies of a market economy.

According to recent reading of Smith (Bragues, 2009), self-interest should be subordinate to moral imperatives, even in the business world. Smith's ideal managers will endeavor to personally live up to the standards enforced by an impartial spectator of his conduct, an internalized onlooker reflecting the ethical requirements posed by the society. Smith makes obedience to the norms of justice the moral condition in exercising one's economic freedom. He argues that without a sense of justice, the worry and fear of potential harms suffered at the hands of others would make market exchanges unconceivable.

Thus, justice is the foundation that supports the building, the main pillar of a market economy. Viewing economic freedom and norms of justice as the two essential preconditions for a free market economy, Smith wrote, "Everyman, as long as he does not violate the laws of justice is left perfectly free to pursue his own interest his 
own way, and to bring both his industry and capital into competition with those of any other man, or order of men," (Smith, A. 1776/2003, IV. Ix. 51). In his view, justice, like benevolence, calls to serve others.

However, what others might do for us out of justice is something over which we have a perfect right. Therefore, doing justice is a moral obligation, not an option. Correspondingly, it is our obligation to do no harm to others' life, promote their security and integrity, and respect for their property, pay due regard for their reputation, and perform contractual agreements.

Similar to Smith, Kant believes that an ethics devoid of the dictates of justice leads to only the clash, compromise, and occasional convergence of individual perspectives. To him, justice is a condition in which each individual's external freedom is restricted so as to make it consistent with the freedom of all others in the framework of a common law or systems of law (Paley, 2002). Apparently, Freedom is an inviolable human right only limited by other people's right of freedom. In short, given the positive meaning of freedom, justice becomes the cornerstone of the morality. Viewing will itself as the source of morality, and moral laws derived from reason as the laws of freedom, Kant's moral philosophy has greatly enriched ethics of justice.

Both Smith and Kant's work made a great contribution to ethics of justice. Nonetheless, ethics of justice or morality of justice is a term coined by moral psychologists to describe the morality and moral reasoning depicted in Kohlberg's model of moral development. According to cross cultural psychologists (Haidt and Graham, 2007; Shweder, 1990; 1997), morality of justice is at the core of ethics of autonomy and has been the dominant conception of morality in the developed countries or the Western world. Justice is an other-regarding moral value, and the morality of justice is generally defined by the injunction of not to treat others unfairly. Justice is all about protecting the rights and autonomy of individuals (Chen et al., 2022; Shweder, 1997). Because it focuses on the rights and duties of individuals, morality of justice is regarded at the center of individualizing ethics, or individual-centered ethics (Haidt, 2001).

Why it is essential to embrace morality of justice in transforming the normative ethics in emerging economies? There are at least three reasons. First, the moral values and principles of traditional normative ethics may not be compatible, sometimes even conflicting with market ethic. Market exchanges presuppose an autonomous individuals who voluntarily enter the exchange relationships to promote their self-interest. Consequently, individuality, freedom of choice, personal responsibility and property rights are at the core of market ethic.

However, central to traditional morality are moral values of benevolence, loyalty, and conformity. Traditional normative ethics emphasizes putting others' interest first, doing whatever it takes to help those who are in need, sacrificing personal 
interest for one's group, complying with the needs and will of collectives, being loyal to the paternal leader of the community, and obeying the will of authority. Such moral values and norms apparently are not compatible with the moral values pertaining to personal rights, rational self-interest, freedom of choice, and autonomy of individuals.

Secondly, traditional morality is not concerned with impersonal market relationships and hence unable to provide regulatory concepts that form the ethical foundation for an economy based on exchange relationships. Neither is it suitable for a civil society rooted in a market economic system. According to Smith, traditional moral values such as benevolence is of limited efficacy in economic life. In a market economy, it is individuals' self-interest that motivates each party to enter the exchange relationship, which in turn, through an invisible hand, promote public interest (Smith, 1776/2003, L.ii.2). "Benevolence is about helping others when one does not have to and when, therefore, neglecting to do so will not draw resentment and punishment" (Bragues, 2009, p. 454).

In a market economy, the personal gains or profit motive drive individuals or firms to put their scarce resources to the highest valued uses while satisfying the needs of their customers. In typical exchange relationships, most people that marketers deal with in a business-based network are strangers or accountancies who are outside one's circle of benevolent concern. Smith puts, "It is not from the benevolence of the butcher, the brewer, or the baker, that we expect our dinner, but from their regard to their own interest. We address ourselves, not to their humanity but to their self-love, and never talk to them of our own necessities but of their advantages" (ibid). Apparently, benevolence plays a very limited role in market relationships ${ }^{2}$.

Thirdly, Market exchanges are voluntary, mutually beneficial, and cooperative relationships, through which each party to the exchange obtains what he or she wants by giving up something of value to the other party. What is needed in such relationships is a different kind of morality, a morality that acknowledge independence of personal interest, and protect individuals' right to private property, and safeguard autonomy of each party. It is morality of justice that evolved in response to the need of a market economy built on impersonal exchange relationships. Its moral domain concerns prescriptive judgments of justice, rights, and welfare that pertain to how individuals ought to relate to each other (Turiel, 1983; Punzo and Naomi, 1993). If right-based ethics is primarily concerned with the

\footnotetext{
${ }^{2}$ In The Theory of Moral Sentiments, Smith offers a few qualification to his discounting of benevolence. For instance, he states, in countries where government authority is weak, and family-based network are tighter and more extended, harnessing kin benevolence via family businesses may help build trust and consequently facilitate the exchange relationship between parties to the exchange.
} 
good of the individual, justice is directly oriented toward the good of others and focuses on the values that affect other people.

Accordingly, justice safeguards impartial and fair exchanges between an individual and others or between an individual and the community. Justice ensures stability of possession, voluntary transference of ownership, and fulfillment of contractual responsibilities that are essential for effective and fair market exchange. As such, justice is viewed as a cornerstone of a market economy and a fundamental pillar of ordered modern society (Rawls, 1971; 1993).

Moreover, ethics of justice separates actions from moral agents and focuses on the moral nature of actions or rightness of conduct. Morality of justice is said to be action-oriented. Morality of justice involves moral prescriptions or social regulation of human conduct/action based on moral rules and principles. Unlike virtue ethics that makes virtue the central concern and focuses on pursuing good life by nurturing moral character, ethics of justice regards the moral person as an agent who objectively adjudicates moral dilemmas. When confronted with a moral problem, it asks, "what should I do?" rather than "what should I be" (Punzo and Naomi, 1993).

To morality of justice, moral conduct is primarily a matter of following or applying moral principles or rules to a particular situation. As Smith puts, the general rules of morality are "the ultimate foundations of what is just and unjust in human conduct" (Smith, 1776/2003, III.i.98). Unlike other human virtues, rules of justice require a sense of duty. Complying with rules of justice is obligatory. Hence, ethics of justice is duty-based because people are obliged to behave in accordance with rules of morality of justice.

What is meant by justice? In his formal conceptualization, Aristotle ${ }^{3}$ maintains that justice entails to treat equals equally and unequal unequally. Equality and reciprocity are at the core of morality of justice. That is, the meaning of justice, in its broadest sense, is "fairness." It implies that we behave toward others in an impartial manner with the goal of treating others equally. Justice also means dealing with others as one would like to be dealt with oneself. Theories of justice are tied to conceptions of human rights, which speak to people's basic needs, such as decent stand of living, education, and medical care.

According to Nilsen (2005), justice is primarily concerned with the allocation of resources necessary to enable each person to live a life in dignity. Justice is particularly about protecting the individuals' autonomy and welfare against external

\footnotetext{
${ }^{3}$ Aristotle's concept of justice presumes two aspects: commutative justice and distributive justice. The first consists of the equality to give to everyone a value equivalent to the value performed. The second consists in giving to everyone their merits, goods, honor, it is a proportional equality.
} 
harm or coercion. It is of necessity that fairness and justice evolved into guiding moral principles. The moral principles of justice permeates various aspects of our society. For instance, in the judicial system, justice calls for due process during judicial proceeding that require a clearly specified procedures for both sides to be heard. It also requires a process for appeals be available to both sides.

The principles of equality, reciprocity, equity, fairness, and mutual respect are central to morality of justice. Equality is one of the core principles in a just society. The concept of social equality maintains that every person is of equal intrinsic worth as others and all individuals should therefore be entitled to equal rights, opportunities, responsibilities and treatment. Social equality is essential for justice as the dignity of the person cannot be achieved if some people have control over others, or have more power than others concerning public affairs. Equality entails to give all people an equal place and choice at decision-making tables and promotes an equitable share of the social resources (Bonnycastle, 2011).

In the case of market relationships, the principle of equality means all the individuals enjoys equal right to their possession or private property, and equal right to selfpreference and autonomy. As Kline (2010, p. 245) puts, markets rely on enforced moral rules for its very existence "The core rules that constitute the foundation of any market are the rights to life, bodily integrity, property, trade, and contract".

These rules are the rules of game in the markets. These rules of justice ensure the stability of property possession, voluntary transfer of ownership, and contractual commitment. Thus, it is unjust to steal property, acquire property by coercion, or violate business contracts. To engage in a market relationship is to respect these rights in the process of exchanges. Kline argues that protecting those rights also means to protect people from harm or any violation of others' welfare interests.

The morality of justice requires moral agents to be impartial in their ethical decisionmaking, which entails that we must treat ourselves as one among others, giving the interests of others the same weight we give our own. The concept of fairness lives in a rule space, for fair interaction places emphasis on rules and procedures, which are blind to the individual players' interests. John Rawls, one of the most distinguished contemporary justice theorist argued due to the potential of conflict among individuals as pursuing divergent goals, there must be a set of governing principles to ensure fairness.

Rawls (1971) reasoned that this set of principles would emerge when rational people bargained for them under the "original position," or from "veil of ignorance." Because under the original positon, people have no knowledge about their own status or level of privilege relative to others, they will be motivated to bargain in a way that is impartial and considerate, thus ensuring fairness for all. 


\section{Concluding Comments}

As emerging countries experience dramatic changes when shifting to a market economy, the need for a new types of ethics or moral transformation becomes increasingly important. Some traditional moral belief, values and ethical norms are being replaced by the new and some be revitalized to get a hold in the making of the new normative ethics. These changes will take a long time and fundamentally transform the existing ethical system. Because economic reform comes with beliefs and values that are inconsistent with and sometime in opposition to the traditional values, constructing a workable and reasonable business ethics for emerging economies is a daunting task.

As the above discussion indicates, the real challenges in developing a new system of ethics lies in how to integrate market ethic with moral responsibility, first and foremost, how to balance the profit concern with ethical and social responsibility, and self-interest pursuit with protection others' interest and freedom of choice. Ethics of justice, as the rule-based modern morality, is in sharp contrast with traditional ethics of community and/or virtue ethics.

Thus, it is by no means an easy task to incorporate changes in moral principles and values brought about by economic reform into the existing normative ethics, and/or ideological system. Nonetheless, a new value system and ideology seem to be essential to the continuing development of a market economy. It is of historical significance for business researchers to enhance their intellectual effort in both theoretical and practical research in this regard.

In the present study, we have concentrated on discussion of the need and importance of exploring and building ethical foundation for transforming economies. It is a "must" to conclude this paper by arguing that ethics alone is not enough to solve the ethical doldrums emerging countries are now facing. The confusions and chaotic situations we are facing in emerging economies are the consequences of a combination of cultural, institutional, organizational, and motivational causes, each of which may be complex enough by itself.

Needless to say, emerging countries need to enhance institutional development, strengthen legislation and law enforcement, and fortify free press among others, to supplement the ethical effort. This is a tall order. But the failure to do so will exact a high cost on those countries and their people.

\section{References:}

Balsiger, P. 2016. Moral struggles in markets. The fight against battery cages and the rise of cage-free eggs in Switzerland. European Journal of Sociology, 57(3), 419-450.

Berger, R. 2015. The transformation of Chinese business ethics in line with its emergence as a global economic leader. Journal of Chinese Economic and Foreign Trade Studies, 
8(2) 106-122.

Bonnycastle, C.R. 2011. Social justice along a Continuum: A relational illustrative model. Social Service Review, 85(2), 267-295.

Bragues, G. 2009. Adam Smith's Vision of the Ethical Manager. Journal of Business Ethics, 90, 447-460.

Chen, N.Y.F., Li, F., Feng, S., Zhang, S. 2020. Moral disengagement and moral judgment: The roles of moral endorsement, shareholder-value orientation, and intensity of moral issues. Ethics and Behavior. doi:10.1080/10508422.2020.1744149.

Evensky, J. 2005. Adam Smith's theory of moral sentiments: On morals and why they matter to a liberal society of free people and free markets. The Journal of Economic Perspectives, 19(3), 109-130.

Hanafin, J.J. 2002. Morality and the market in China: Some contemporary views. Business Ethics Quarterly, 12(1), 1-18.

Hashmi, M.A., Damanhouri, A., Rana, D. 2015. Evaluation of sustainability practices in the United States and large corporations. Journal of Business Ethics, 127, 673-681.

Haidt, J. 2001. The emotional dog and its rational tail: A social intuitionist approach to moral judgment. Psychological Review, 108(4), 814-834.

Haidt, J., Graham, J. 2007. When morality opposes justice: conservatives have moral intuitions that liberals may not recognize. Social Justice Research, 20(1), 98-116.

Ip, P.K. 2009. The challenge of developing a business ethics in China. Journal of Business Ethics, 88, 211-224.

Javalgi, R.G., Russel, L.T.M. 2018. International marketing ethics: A literature review and research agenda. Journal of Business Ethics, 148, 703-720.

Kant, I. 1785/2012. Groundwork of the Metaphysics of Morals. UK, Cambridge University Press.

Kline, W. 2010. Do no harm: A defense of markets in healthcare. HEC Forum, 22, 241-251.

Li, F., Wang, X., Kashyap, R. 2019. Socially responsible practice and CSR orientation of Chinese managers: The role of Confucian ethics and Confucian dynamism. Sustainability, 11(2), 1-13.

Li, Y., Yao, F.K., Ahlstrom, D. 2015. The social dilemma of bribery in emerging economies: a dynamic model of emotion, social value, and institutional uncertainty. Asia Pacific Journal of Management, 32, 311-334.

Li, Z.J. 2018. Brief History of China's Reform. People Press, Beijing China.

Lu, X.H. 1997. Business Ethics in China. Journal of Business Ethics, 16(14), 1509-1518.

Maitland, I. 1997. Virtuous markets. Business Ethics Quarterly, 7(1), 17-31.

Maitland, I. 2002. The human face of self-interest. Journal of Business Ethics, 38(1-2), 3-17.

Nilsen, E. 2005. Coercion and Justice: A Critical Analysis of Compulsory Intervention towards adult Substance Abusers in Scandinavain Social Law. International Journal of Social Welfare, 14, 134-144.

North, D.D. 1995. The Adam Smith Address: EconomicTheory in a Dynamic Eonomics. Business Economics, 30(1), 7-18.

Paley, J. 2002. Virtues of Autonomy: The Kantian ethics of care. Nursing Philosophy, 3, 133143.

Peng, M.W., Heath, P.S. 1996. The growth of the firm in planned economies in transition: Institutions, organizations, and strategic choice. The Academy of Management Review, 21(2), 492-528.

Punzo, V. A., Meara, N.M. 1993. The virtues of a psychology of personal morality. Journal of Theoretical and Philosophical Psychology, 13(1), 25-39.

Rawls, J. 1971. A theory of Justice. Harvard University Press, Cambridge, MA. 
Rawls, J. 1993. Political Liberalism. Columbia University Press. New York, NY.

Redfern, K., Crawford, J. 2004. An empirical investigation of the influence of modernisation on the moral judgments of managers in the People's Republic of China. Cross Cultural Management, 11(1), 48-61.

Salvador, R. 2019. Perceived forgiveness climate and punishment of ethical misconduct. Management Decision, 58(5), 797-811. https://doi.org/10.1108/MD-06-2018-0650.

Shweder, R. 1990. In defense of moral realism: Replay to Gabennesch. Child Deve., 61, 2060-2067.

Shweder, R.A., Much, N.C., Mahapatra, M., Park, L. 1997. The 'Big Three' of morality (autonomous, community, and divinity), and the 'Big Three' explanations of suffering. In: A. Brandt, P. Rozin (Eds.). Morality and Health, 119-169. New York: Routledge.

Smith, A. 1759/1966. The Theory of Moral Sentiments. Reprints of Economic Classics. New York, Sentry Press.

Smith, A. 1776/2003. An Inquiry into the Nature and Causes of the Wealth of Nations. New York, Bantam Dell, Random House.

Tam, O.K. 2002. Ethical issues in the evolution of corporate governance in China. Journal of Business Ethics, 537, 303-320.

Turiel, E. 1983. The Development of Social Knowledge: Morality and Convention.

Cambridge, England, Cambridge University Press.

Vasquez, M.J. 2012. Psychology and Social justice. American Psychologist, 67(5), 337-346. 